\title{
A palavra em movimento no filme 0 Intendente Sansho, de Kenji Mizoguchi
} The word in motion in the film Sansho the bailiff, de Kenji Mizoguchi

Maria Schtine Viana ${ }^{1}$

\footnotetext{
${ }^{1}$ Doutoranda no Departamento de Estudos Portugueses da Faculdade de Ciências Sociais e Humanas da Universidade Nova de Lisboa (FCSH-UNL). Mestre em Culturas e Identidades Brasileiras pelo Instituto de Estudos Brasileiros da Universidade de São Paulo (IEB-USP).E-mail: mariaviana8@uol.com.br
} 
Resumo: por meio deste ensaio, pretende-se estabelecer uma relação entre a literatura e o cinema a partir da leitura de cenas e efeitos sonoros do filme Sanshô Daŷ̂ (O Intendente Sansho, 1954), do cineasta japonês Kenji Mizoguchi, posto que o roteiro do filme foi escrito a partir de novela homônima de Ogai Mori. Para tanto se destacará a importância da articulação entre a nomeação das personagens e a palavra (cantada e escrita) na montagem desse clássico do cinema japonês.

Palavras-chave: O intendente Sansho; Kenji Mizoguchi; cinema; literatura.

Abstract: the aim of this essay is to establish a relationship between literature and cinema by analyzing scenes and sound effects of Sanshū Dayū (Sansho the bailiff, 1954) by the Japanese director Kenji Mizoguchi, since the screenplay of the film was written from the homonymous novel by Ogai Mori. To that end, I will highlight the importance of the articulation between the naming of the characters and the word (sung and writing) in the assembly of this classic of the Japanese cinema.

Keywords: Sansho the bailiff; Kenji Mizoguchi; cinema; literature. 


\section{Da novela ao filme}

O filme O intendente Sansho (Sanshô Dayû), rodado em 1954, é um dos últimos da profícua carreira do cineasta japonês Kenji Mizoguchi, iniciada em 1923. O roteiro foi escrito por Fuji Yahiro e Yoshikata Yoda. O ponto de partida foi a narrativa homônima de Ogai Mori², que, por sua vez, inspirou-se em relato recolhido da tradição oral budista.

A novela ${ }^{3}$ tem início como no filme, com a caminhada de uma mulher, acompanhada pelos filhos Anju e Zushio e por sua serva fiel, em busca do pai das crianças, que viajara para Tsukushi. A demora do marido em retornar para casa é o motivo que deflagra a partida da pequena comitiva da cidade natal. A separação entre mãe e filhos por pessoas de má índole é o momento de viragem, tanto na narrativa de Ogai Mori como no filme de Mizoguchi. A figura assustadora do cruel intendente Sansho e a situação de penúria à qual as crianças são submetidas quando escravizadas também são similares nas duas narrativas.

Todavia, se na novela Anju é a portadora do amuleto de Jizo, a protetora dos viajantes, no filme a substituição desse amuleto pelo da deusa da misericórdia, Kannan, não apenas faz da compaixão o tema central da narrativa como dá à estatueta dessa deidade importância fundamental, como se verá no decorrer deste ensaio. Se na novela as crianças são marcadas a ferro e curadas miraculosamente por Jizo, embora tudo não passasse de um sonho, na obra de Mizoguchi, ainda que os irmãos não sofram esse castigo, tal flagelação é apresentada de forma bastante real. A morte da serva e de Anju nas águas também é recorrente nos dois suportes.

Nas narrativas da tradição oral, de onde advém a versão de Mori, algumas informações, como “por que o pai partiu de casa?” e sobretudo a intervenção do sobrenatural, são comuns, mas não funcionariam em um filme realista, no qual Mizoguchi tinha como objetivo retratar a crueldade dos senhores feudais.

\footnotetext{
${ }^{2}$ Rintaro Mori (1862-1922) usou o pseudônimo Ogai para assinar suas novelas escritas sob a influência da produção europeia. Filho de um médico da localidade de Tsuwano (atual província de Shimane), licenciou-se em medicina em Tóquio e, com 22 anos, recebeu uma bolsa de estudos para realizar sua especialização na Alemanha. Foi durante essa estadia de quatro anos em solo germânico que não apenas aperfeiçoou seus conhecimentos da língua alemã como recebeu grande influência da produção literária europeia. Ao retornar para o Japão, em 1888, traduziu para o japonês várias obras de escritores como Daudet, Byron, Shakespeare, Goethe, Schiller, Heine, entre outros. Grande foi também sua contribuição para o teatro moderno japonês, pois, além de traduzir peças de Ibsen e Hermann Sudermann, produziu peças de teatro e escreveu crítica teatral.
}

${ }^{3}$ Refiro-me à edição espanhola, que recebeu o título El intendente Sansho (2014). 
Em depoimento sobre sua longa parceria com Mizoguchi, Yoshikata Yoda, argumentista que assinou parcerias com Kenji por duas décadas, conta que inicialmente o roteiro fora escrito por Yahiro, que fizera uma adaptação excelente, mas bastante próxima da novela de Mori. O realizador rejeitou essa primeira versão por se recusar a trabalhar com um elenco infantil. O argumento foi, então, reescrito por Yoda, que manteve as cenas iniciais bem próximas do enredo da novela, mas, na maior parte do roteiro, afastou-se bastante da narrativa original. Explica também que foi justamente a partir de questões como “por que o marido não estava lá?” e “por que não voltou para casa?" que Mizoguchi o induziu a pensar que o marido fora exilado por discordar da política governamental.

Ele havia provocado a cólera do chefe de Estado, que discordava de suas ideias sobre igualdade e sua luta em defesa dos escravos e camponeses. Essa ideologia se confundia com sua forte vocação religiosa. Por isso, ao partir para o exílio, o patriarca deixa com os filhos uma preciosa e rara estatueta de Buda. (YODA, 1997, p. 118, tradução minha)

A dedução de Mizoguchi teria levado o roteirista a construir a personagem do pai como generoso e misericordioso, caráter bem expresso na máxima ensinada ao filho enquanto lhe entregava a imagem da deusa budista: "Sem compaixão o homem é um animal. Mesmo que sejas severo consigo mesmo, deverás ser misericordioso com os outros" (O intendente Sansho, 1954). Esse ensinamento reverberará na memória de Zushio por muito tempo. Contudo, os horrores da escravidão farão com que ele o esqueça, a ponto de marcar sem piedade um ancião fugitivo e se prontificar a conduzir uma pobre moribunda para ser devorada por aves de rapina.

Cabe ressaltar que o final do filme é bem diferente do apresentado na novela. Na narrativa de Mori, a mãe das crianças recupera a visão por intermédio da intervenção miraculosa de Jizo, a protetora dos viajantes. Isso não acontece na película de Mizoguchi. De acordo com Yoda, o realizador chegou a filmar dois finais, mas acabou optando por manter a cegueira da mãe e, consequentemente, a força poética da montagem, explorando-a como um efeito.

\section{Cerimônias de nomeação}

O fato de um nome próprio ser usado na composição do título já indica a preponderância da nomeação no filme. Os nomes dos irmãos que protagonizam a novela foram mantidos no roteiro cinematográfico, e as crianças guardarão segredo sobre sua verdadeira identidade quando vendidas como escravas. Aspecto 
fundamental, já que é justamente o segredo sobre a origem delas que ajudará a manter a estrutura narrativa, tanto no texto literário como no filme.

$\mathrm{Na}$ novela, os acontecimentos se sobrepõem às ações das personagens, como bem aponta V. Chklovski: "Geralmente, a novela é uma combinação das construções em caracol e em patamares, e, além disso, complicadas por diversos desenvolvimentos" (1989, p. 50). É exatamente essa construção circular, ou em estrutura de novelo, presente no texto literário que foi mantida também no filme. Basta lembrar que na película as personagens são sempre tragadas por situações externas que determinarão seu destino: o pai é destituído pelo exército local; mãe e filhos ficam um tempo na casa dos parentes, de onde têm de partir; são interceptados por pessoas de má índole e vendidos como escravos; Zushio é lançado na prisão e depois reconhecido como filho do governador destituído; torna-se um líder justo e tem de abrir mão desse cargo por não ser conivente com as leis locais. Entretanto, grande parte desse ciclo tão peculiar da novela não teria sido possível se o segredo sobre os nomes não fosse mantido. Ou seja, o enigma em torno da verdadeira identidade das crianças é que mantém a força da intriga até o desfecho inesperado.

Cabe ressaltar que, se na novela o nome de Anju passa a ser Shinobugusa, cujo significado é "erva paciente como o sofrimento", no filme seu nome não está longe desse, significando "aquela que tudo suporta com paciência”. Não é esse o caso de Zushio. No roteiro de Yoda, ser-lhe-á dado o nome da província de onde veio, Mutsu-Waka, bem diferente do recebido na novela, Wagana Wo Wasuregusa, "erva que esquecerá seu nome”. Yoda genialmente utiliza esse aspecto na caracterização da personagem. Embora o jovem não se esqueça do próprio nome, distancia-se do proceder que o genitor gostaria que ele assumisse, ou seja, ser misericordioso com outrem, mesmo que para tanto fosse cruel consigo mesmo.

A terceira nomeação, da qual apenas Zushio participará, antecede a leitura do édito conduzida pelo primeiro ministro, que fará dele o novo governador de Tango. Ali, portanto, a nomeação verbal não é apenas declarada, mas lida em um documento oficial. Sob o novo nome, Massamichi Taiara, ele se sente investido de poderes para libertar não só a irmã, Anju, mas os outros escravizados, ainda que o primeiro-ministro lhe explique os limites de sua atuação.

Todo esse mistério em torno dos nomes omitidos pelas crianças é fundamental na trama do filme e será o elemento que não apenas desencadeará o desejo de fuga de Anju para reencontrar a mãe, quando recebe informações sobre ela, como servirá de sonorização para os momentos mais comoventes do filme, recurso bem explicado por Robert Stam: 
Assim como a proferição literária cria a situação à qual ela se referemais do que meramente imitar algum estado de coisas préexistente - poder-se-ia dizer que a adaptação cinematográfica cria uma nova situação áudio-visual-verbal, mais do que meramente imitar o velho estado de coisas como representado pelo romance original. A adaptação assim molda novos mundos mais do que simplesmente retrata/trai mundos antigos. (2006, p. 52)

\section{Do chamamento à canção: o percurso dos nomes}

Na noite anterior ao trágico destino da senhora Tamaki, que jamais poderia imaginar que seria obrigada a servir como cortesã na ilha de Sado e ter os filhos vendidos como escravos, ela os autoriza a afastarem-se dela para colher seixos e galhos, com os quais construirão uma cabana para passar a noite. Uma sonorização alegre começa justamente quando os infantes estão a fazer da tarefa uma brincadeira, caindo no chão a sorrir depois de juntos quebrarem o galho de uma árvore. Súbito a sonorização é suspensa, como se o narrador estivesse a nos indicar que teremos de nos lembrar dessa cena mais adiante. É Anju quem ouvirá primeiro o chamado da mãe, enquanto o irmão pensa tratar-se do barulho das ondas do mar; tomada do rosto angustiado da senhora Tamaki, que grita pelos filhos; corte para as crianças que correm ao encontro daquela que as espera.

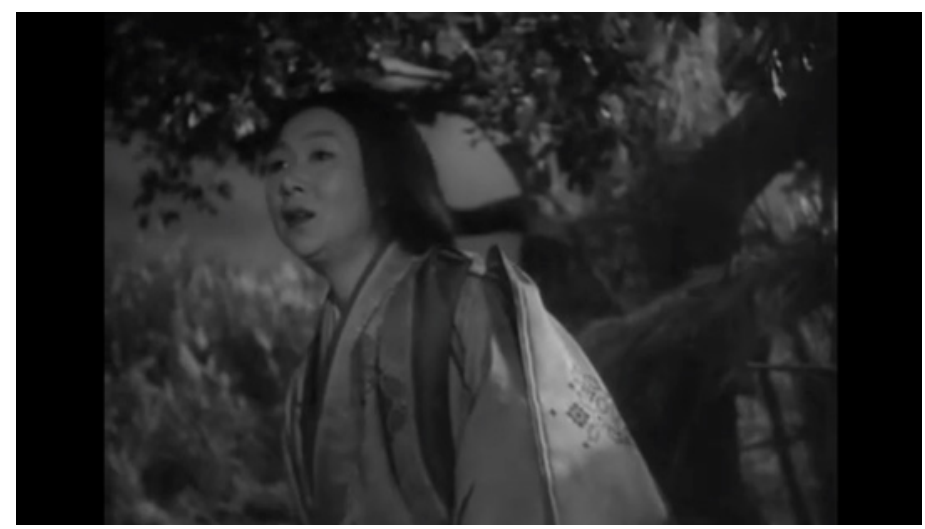

Figura 1: Tomada do rosto da senhora Tamaki, que chama pelos filhos Fonte: Sanshô dayû (O intendente Sansho, 1954).

A segunda vez que a mãe grita o nome dos filhos é quando está no barco. Subjugada pelos barqueiros, percebe tarde demais que caíra em uma cilada, armada pela sacerdotisa. A câmera vai do barco tremulante às crianças na praia, que relutantes 
tentam em vão soltar-se das garras da ardilosa mulher e de outro barqueiro. Essa embarcação oscilante, de onde a mãe grita desesperada, descreve um "movimento catatónico impossível de reprimir, mas esvaziado de outro sentido que não seja o do próprio vazio" (COSTA, 2000, p. 32).

Essa será a última visão que a mãe terá dos dois filhos. Quando é reencontrada por Zushio, está a repetir um movimento catatônico, tocando com um ramo no chão, e é assim que a avistamos na praia.

O seu destino será revelado por meio de uma canção, entoada por uma jovem camponesa, vendida como escrava na ilha de Sado, a quem Anju ensinará a usar a roca de fiar. A novata diz desconhecer o paradeiro de Tamaki-san quando inquirida pela filha em busca de notícias. Anju volta resignada para o trabalho. Ouve-se a primeira estrofe da canção. A câmera segue o rosto de Anju, e não o da cantora. Ela se levanta, vai em direção à jovem, pergunta-lhe onde aprendera aquela música. Kohagi diz tratar-se de uma cantiga popular da ilha de Sado, composta por uma cortesã de nome Nakagimi. Logo, a mãe também trocara de nome. Ouve-se novamente a canção: "Anju, como anseio por ti. Zushio, como anseio por ti. A vida não é mesmo uma tortura?” (O intendente Sansho, 1954).

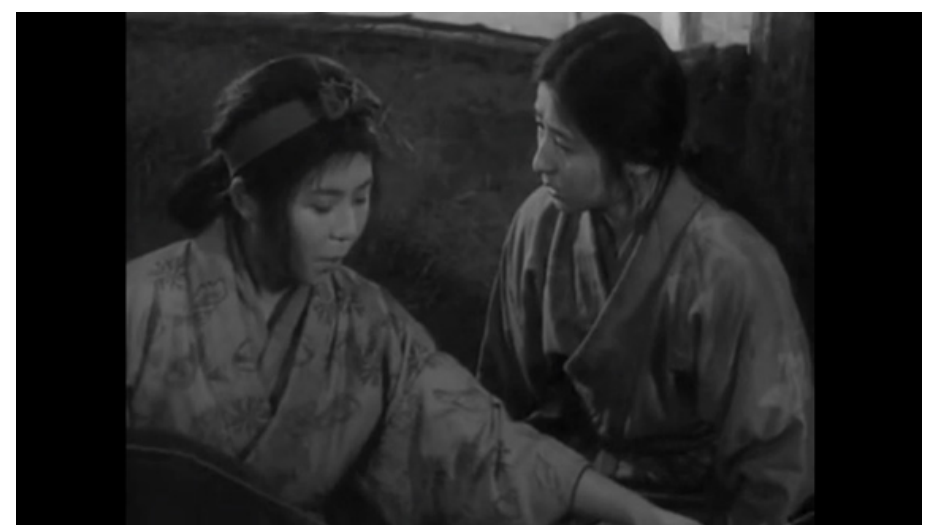

Figura 2: Cena do plano-sequência que acompanha os movimentos de Anju, que chora ao reconhecer a mensagem da mãe, escondida na canção, entoada na bela voz da tecelã, tendo como acompanhamento os ruídos da roca de fiar

Fonte: Sanshô dayû (O intendente Sansho, 1954).

Reconhecidamente um mestre desse tipo de tomada, Mizoguchi diz o seguinte a respeito do uso do plano-sequência:

Comecei a utilizar a técnica do plano-sequência em 1936, consistindo ela em nunca alterar o enquadramento durante 
toda a sequência enquanto a câmara permanece a certa distância. Adoptando este método não tive a mínima intenção de representar o estado estático de uma qualquer psicologia. Pelo contrário, cheguei a ele espontaneamente, prosseguindo à procura de uma expressão mais precisa e mais específica dos momentos de grande intensidade psicológica [...]. Fui naturalmente levado a seguir uma técnica deste tipo pelo simples desejo de evitar o método clássico da descrição psicológica pelo abuso dos grandes planos. (apud MADEIRA, 2005, p. 45)

Depois do choro emocionado de Anju, a mesma canção, com um efeito de eco, sonoriza uma tomada da mãe desesperada a tentar fugir em um barco da ilha de Sado. É ainda a melodia dessa cantiga que se ouvirá quando as mulheres transportam Tamaki-san, que já não pode caminhar sozinha em consequência de um cruel castigo, para o alto da colina de onde ela chama pelos filhos em um lamento.

Não é a canção, mas a repetição do ato de colher palha para construir uma cabana para a moribunda Najimi-san, quando os irmãos voltam a cair ao quebrar um galho, que deflagra o arrependimento do jovem. Todavia, não se ouve a trilha alegre de outrora, mas só a sonorização do ambiente, com ênfase no barulho da quebra do galho e, consequentemente, queda dos irmãos. Ouve-se a voz da mãe, como no passado, mas há água por perto, o que pode ser apenas uma confusão entre os sons, como acontecera outrora. Ao lembrar-se de sua verdadeira natureza, Zushio chora e decide que devem fugir. Anju articula rapidamente o plano de evasão. Ele deverá partir levando a moribunda e a estatueta da deusa. A jovem engana a sentinela no intuito de dar tempo para que o irmão fuja.

Os espectadores sabemos que ele não voltará ao acampamento. Silêncio. Foco no rosto apreensivo de Anju. Ela senta-se em um tronco, atrás dela está a velha Kayano. No segundo plano, avista-se uma placa de madeira. Os guardas percebem que Zushio fugira. Corte para o jovem em fuga. Nova tomada da entrada da casa, Anju olha apreensiva para o portão. A câmera faz um caminho da direita para e esquerda, e vê-se um homem a bater na placa de madeira instalada à entrada da propriedade, para desespero do espectador e da irmã. A fonte do alarme que já fora ouvido duas outras vezes quando outros escravizados evadiram é finalmente revelada em um dos momentos de maior tensão do filme. Para não correr o risco de traí-lo quando torturada, Anju foge tão logo o alarme é acionado.

Os guardas saem em disparada a sua procura. Silêncio. Assiste-se, então, a uma das cenas mais sublimes do filme. Uma névoa iluminada envolve as margens do rio, emoldurado por ramas de bambu. Anju faz uma reverência, tira as sandálias 
e ajeita-as com as mãos. Anda em direção às águas, caminha lentamente até que sua cintura esteja coberta. Silêncio absoluto. Voz da mãe cantando ao fundo, como um chamado. A jovem continua a caminhar, veem-se as sandálias deixadas às margens. Tomada da anciã Kayano, que ajoelha e medita. Panorâmica do lago. Círculos de água em movimento. Silêncio. Passagem para a imagem de Buda, no mosteiro onde monges fazem uma cerimônia, antes da chegada barulhenta dos homens de Sansho. Então, cabe aqui recuperar a indicação da morte de Anju na novela: "Cuando toda la familia del Intendente Sansho salió en busca de Zushio, al pie de esta cuesta, encontraron tan solo un par de pequeñas sandalias de paja. Eran las sandalias de Anju” (MORI, 2014, p. 25).
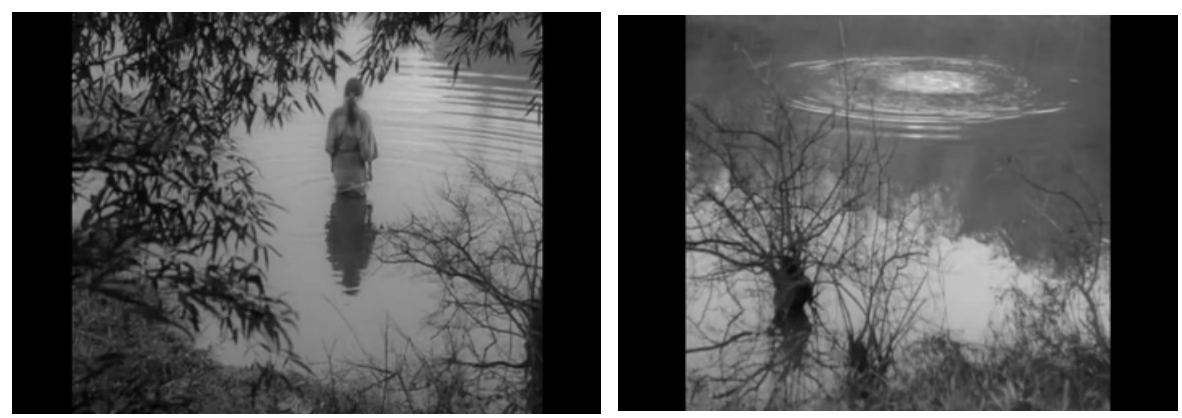

Figura 3: A lenta caminhada de Anju para a morte Fonte: Sanshô dayû (O intendente Sansho, 1954).

Nos momentos finais do filme, a canção é novamente ouvida. Zushio, que já percorrera toda a aldeia em busca da mãe, por acreditar ter sido ela vitimada por um tsunami, está na praia a pedir informações sobre o ocorrido a um coletor de algas. Ouve-se a canção sendo murmurada por uma voz exausta, ao longe. Plano geral dos casebres miseráveis à beira-mar. Traveling acompanha a caminhada do jovem; avista-se um vulto da mulher que murmura a canção. Tamaki-san já não tem forças para gritar ou cantar, mas balbucia a cantiga-chamamento que permite ao filho reconhecê-la. Ele se aproxima da senhora que, com movimentos catatônicos, bate com uma vara no chão. Atrás dela repousa um par de chinelos de palha: como não lembrar das sandálias de Anju, deixadas para trás em sua caminhada para a morte? Estariam ali a indicar que a mãe também simbolicamente morrera desde que fora afastada dos filhos?

Tamaki-san está cega, pensa tratar-se de algum impostor. Deduz-se o quanto ela terá sofrido com a maldade de algum morador que já se fizera passar por seu filho, aproveitando-se da sua cegueira. Por isso, ela reluta em reconhecer 
Zushio. É no final do filme, portanto, que os dois elementos usados como códigos permitem a identificação e são utilizados de maneira sublime. Se a escuta da canção permitiu ao filho reconhecer a mãe, é por meio da imagem da deusa, colocada em suas mãos, que a combalida senhora, por meio do tato, reconhece a imagem e, consequentemente, a presença do filho.

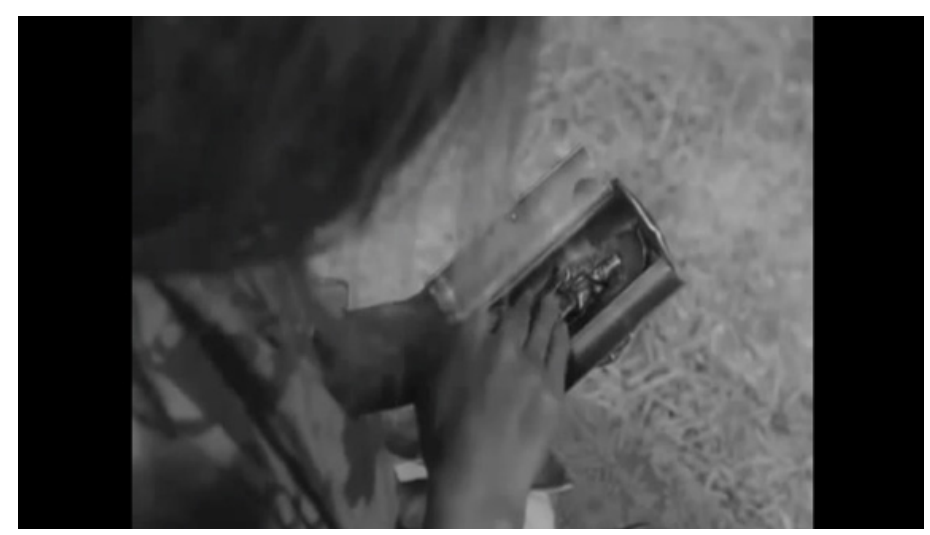

Figura 4: Ao tatear a imagem da deusa, Tamaki-san acredita nas palavras Zushio Fonte: Sanshô daŷu (O intendente Sansho, 1954).

\section{Cenas de escrita e onde a escrita falha}

A primeira tomada em que os ideogramas aparecem é no templo budista, onde Zushio e Najimi-san são acolhidos e escondidos pelos monges. Os capatazes do intendente Sansho invadem o lugar, armados. O monge superior os intercepta com autoridade, dizendo: "Não há foragidos aqui. Este é um templo do império” (O intendente Sansho, 1954). O monge aponta para uma placa, assinada pelo imperador, na qual se lê: "Templo imperial de Tango". Ali apenas a palavra escrita funciona. Não há dúvida de que aquele é um grande templo. As majestosas imagens de Buda por toda parte indicam a sua magnitude. A palavra do monge principal também poderia bastar, mas é ao avistar a assinatura do imperador que o bando sai do templo. Seguem a indicação dada por outro monge, do qual ainda não se vê o rosto. Aquele que estava na sombra aproxima-se da câmera e saberemos tratar-se de Taro, o filho do intendente, que deixara a casa do pai para seguir os ensinamentos de Buda.

A segunda vez em que os ideogramas aparecem no filme é na forma de assinatura do sacerdote-chefe que, a pedido de Taro, escrevera uma carta para 
revelar a verdadeira identidade de Zushio - missiva que em vão ele tenta entregar ao primeiro-ministro, pois acaba arrastado pelos guardas. As sentinelas, acreditando que ele havia roubado a imagem da deusa que carrega consigo, tomam-na dele.

Close-up do primeiro-ministro, que observa minuciosamente a imagem que tem nas mãos. Zushio é conduzido à sua presença. Então, saberemos aquilo que o pai não revelara ao filho quando lhe entregara a imagem: a estatueta de ouro pertencera a antepassados do atual imperador Michinaga e fora dada ao governador deposto como reconhecimento por sua bravura e coragem. É também nessa sequência que acontece mais uma reviravolta na vida da personagem, procedimento tão recorrente no gênero novela: Zushio recebe a triste notícia da morte do pai no exílio e deverá ocupar o cargo de governador de Tango. Portanto, inicialmente a escrita falhou, posto que a carta só foi lida pelo primeiro-ministro após o reconhecimento da imagem, mas foi a confirmação dos dados da carta que permitiu ao jovem recuperar a identidade perdida.

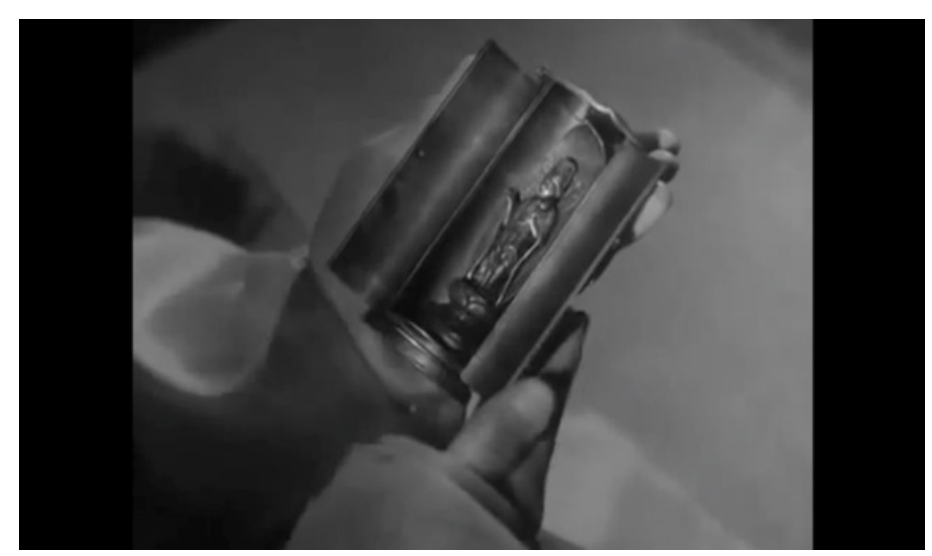

Figura 5: Ao observar a imagem da deusa, o primeiro-ministro reconhece a identidade de Zushio Fonte: Sanshô daŷu (O intendente Sansho, 1954).

Mudança de plano. Zushio está devidamente trajado para a ocasião. Tem início uma nomeação oficial, realizada por meio da leitura de um decreto, por intermédio do qual ele passará a ser chamado de Masamichi Taiara. O primeiroministro abre o segundo rolo. A posição da câmera nos mostra os ideogramas, que são lidos por aquele que nomeia o novo governador de Tango. Desse modo, aqui a escrita e a leitura cumprem de imediato sua dupla função: o jovem recupera não apenas o nome de família como ganha outro epíteto e ocupa oficialmente o lugar que fora do pai como governador. 


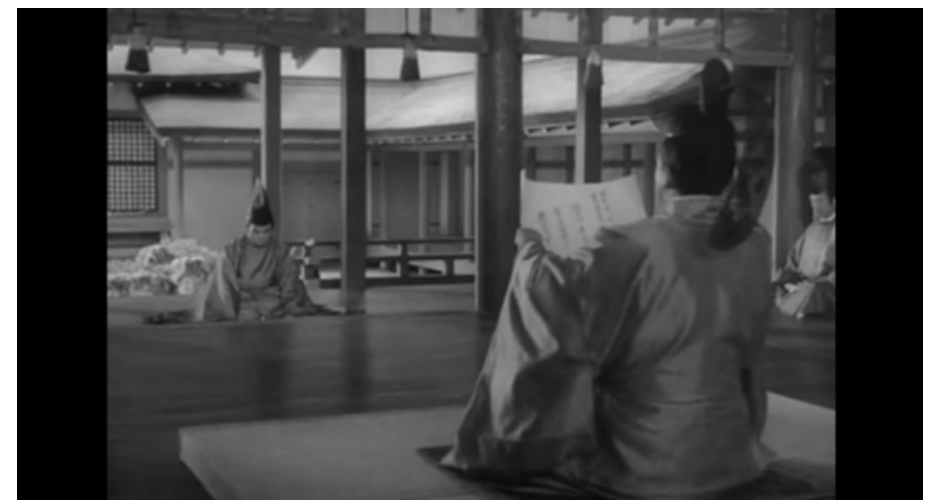

Figura 6: O primeiro-ministro reconhece a identidade de Zushio e lhe concede o cargo de governador

Fonte: Sanshô dayû (O intendente Sansho, 1954).

Já no comando, Zushio, agora como Masamichi Taiara, toma a sua primeira providência: decretar o fim da escravidão. Para espanto do juiz Nomenura, dita ao escriba: "Nesta província a venda de seres humanos está proibida. É proibida pela sanção da lei”. Ouve-se a voz do novo governador, enquanto o foco está nos ideogramas que estão a ser traçados. O escriba suspende o pincel. Ele continua: "O uso de escravos deverá ser proibido tanto em territórios governamentais, quanto em propriedades privadas" (O intendente Sansho, 1954). O foco continua nas mãos do escriba.

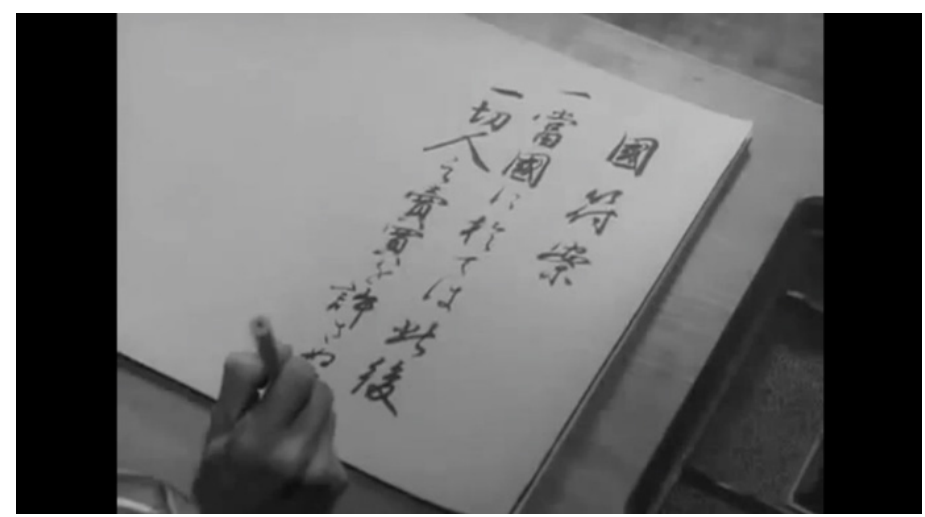

Figura 7: A câmera se detém na mão do escriba Fonte: Sanshô daŷu (O intendente Sansho, 1954).

O juiz tenta dissuadir Zushio, pois como governador não tem quaisquer poderes sobre as propriedades privadas. Avisa-o ainda que o território comandado por Sansho pertence ao ministro da justiça, logo, trata-se de um inimigo forte. 
Plano médio dos três homens, enquanto o novo governador continua a ditar: “Aos escravos libertados deverá ser garantida a escolha de serem enviados para casa ou permanecerem na terra como empregados e serem pagos justamente com dinheiro ou terra. Isto é tudo. Publique isso por toda a província, entendeu?" (O intendente Sansho, 1954).

Seguem-se várias situações em que a palavra-decreto, que foi ditada pelo governador, escrita em papel e transcrita para o suporte de madeira, é apresentada aos aldeões. Na primeira tomada, os guardas do governador conseguem instalá-la. Um homem, que, por suas vestes e uso de chapéu, diferencia-se dos camponeses, lê para os demais, por certo analfabetos, a nova lei. Tomada da placa do ponto de vista dos camponeses, mas em destaque, enquanto ouve-se a voz do leitor ao fundo. ${ }^{4}$
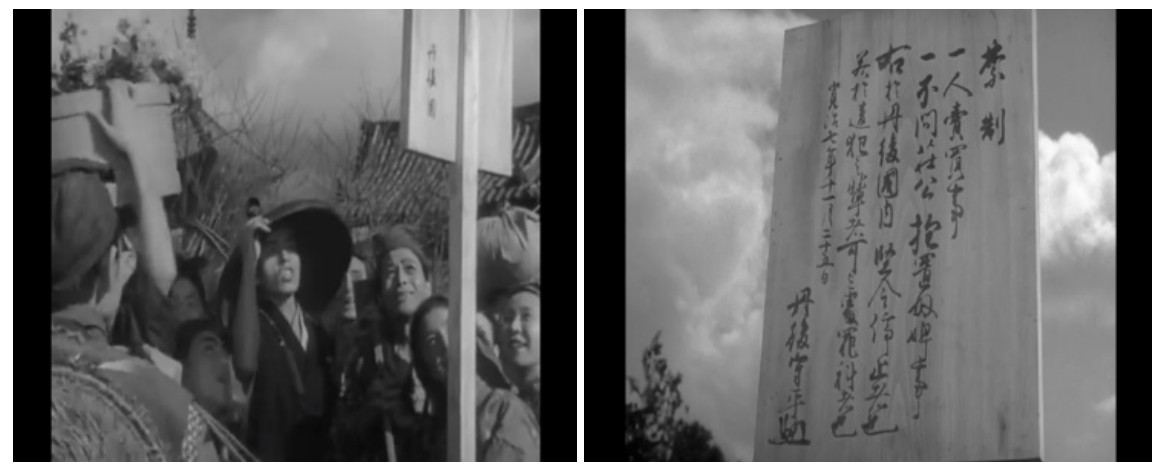

Figura 8: O leitor destaca-se entre os demais camponeses

Fonte: Sanshô dayû (O intendente Sansho, 1954).

Em pouco tempo o intendente Sansho toma conhecimento do decreto e ordena que alguém vá a Quioto avisar ao primeiro-ministro o que está a ocorrer. Ciente de que uma revolta pode ser deflagrada caso os escravizados tomem ciência da lei, ordena que as placas sejam destruídas. Tomada de uma placa sendo lida com escárnio pelos homens de Sansho, antes de ser destruída a machadadas. Em outra cena, um camponês pergunta o que está escrito, ao que outro responde que não sabe ler. Diálogo interrompido pelos capatazes que lançam a placa no rio.

\footnotetext{
${ }^{4}$ Cabe lembrar que, quando visita o túmulo do pai, ao vê-lo enfeitado com flores frescas, Zushio vem a saber que isso fora obra das pessoas do lugar, a quem o governador deposto tratava com bondade, ensinando-lhes a ler e escrever. Logo, o governador, mesmo depois de destituído, acreditava no poder da palavra escrita e na importância de sua decodificação.
} 
A última sequência é a mais longa e a mais interessante. Os guardas do governador mal terminam de colocar a placa, um camponês grita: "Estamos livres!” (O intendente Sansho, 1954). Mas os capatazes arrancam-na, e tem início uma sequência de luta entre os soldados do governador e os homens de Sansho. Nesse traveling, a placa é passada de mão em mão, como um bem precioso que precisa ser protegido com a própria vida pelos guardas, e é o que acontece. Basta lembrar da cena na qual se vê um dos homens do governador ser apunhalado no segundo plano, enquanto no primeiro a placa é destruída por um dos seguidores do intendente. Aqui, a palavra escrita falha, a despeito do empenho dos poucos que sabem ler em compartilhá-la, e dos soldados fiéis terem-na protegido com a própria vida.

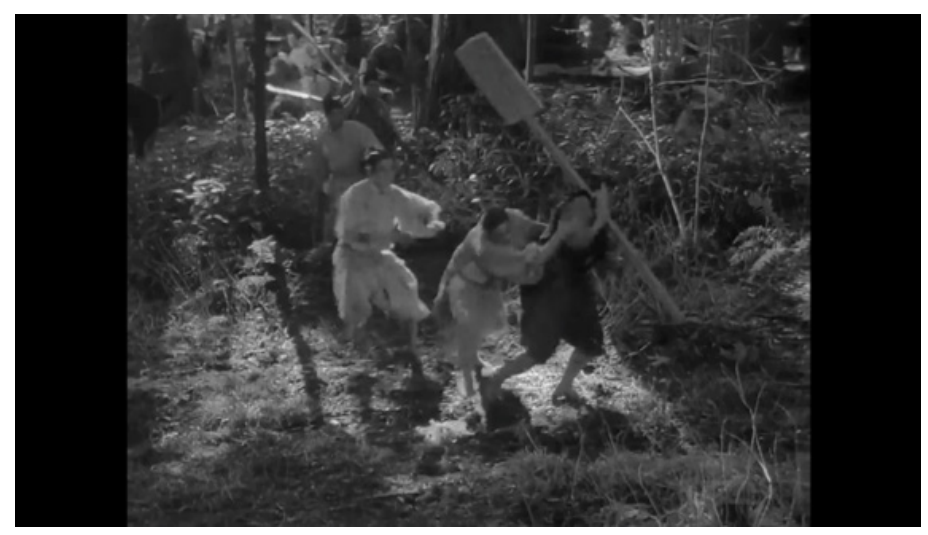

Figura 9: Soldados tentam recuperar a placa com as ordens do governador Fonte: Sanshô dayû (O intendente Sansho, 1954).

Ao saber do insucesso de suas ordens, tanto na busca pela irmã, que ele ainda não sabe morta, quanto no cumprimento de suas leis, o novo governador vai ao encontro de Sansho. Depois de decretar a prisão do cruel intendente e enviá-lo para o exílio, o governador usará a palavra falada onde a escrita falhara. As mesmas leis escritas no édito são pronunciadas por ele aos escravizados, que, finalmente, são libertados pela voz de comando do governador. 


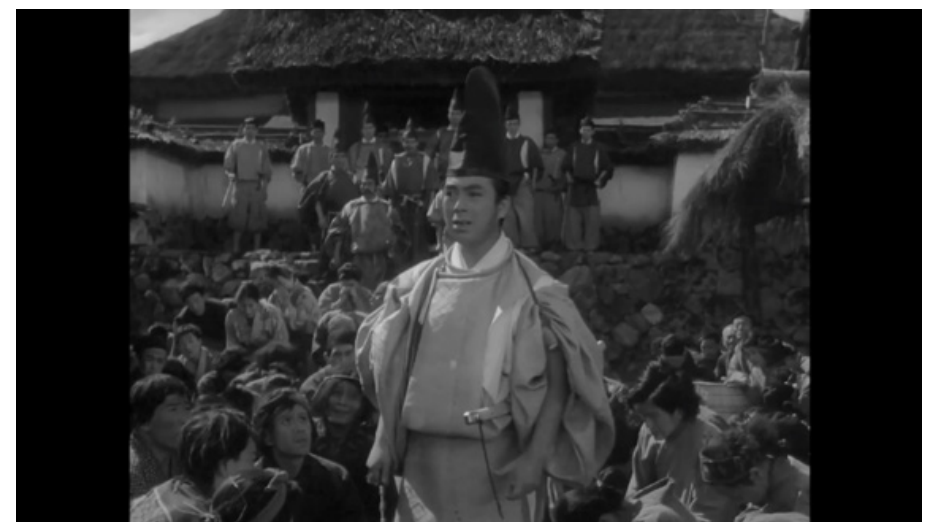

Figura 10: Zushio liberta pessoalmente os escravizados Fonte: Sanshô dayû (O intendente Sansho, 1954).

A última vez que a palavra escrita é utilizada se dá pelas mãos do próprio governador. Seus guardas entram na sala onde ele acabara de selar uma carta. Avisam-no que os camponeses atearam fogo na casa do intendente Sansho, e é pelos olhos dele, que se dirigem a uma janela, que vemos a casa em chamas ao longe.

A carta que não fora ditada, mas escrita pelo próprio governador, está endereçada àquele que o nomeara, pois se trata da demissão do cargo que lhe fora outorgado. Vê-se sua sombra através da cortina de palha de arroz ao dar sua última ordem: "Partirei para a ilha de Sado amanhã, cuidem dos preparativos!" (O intendente Sansho, 1954).

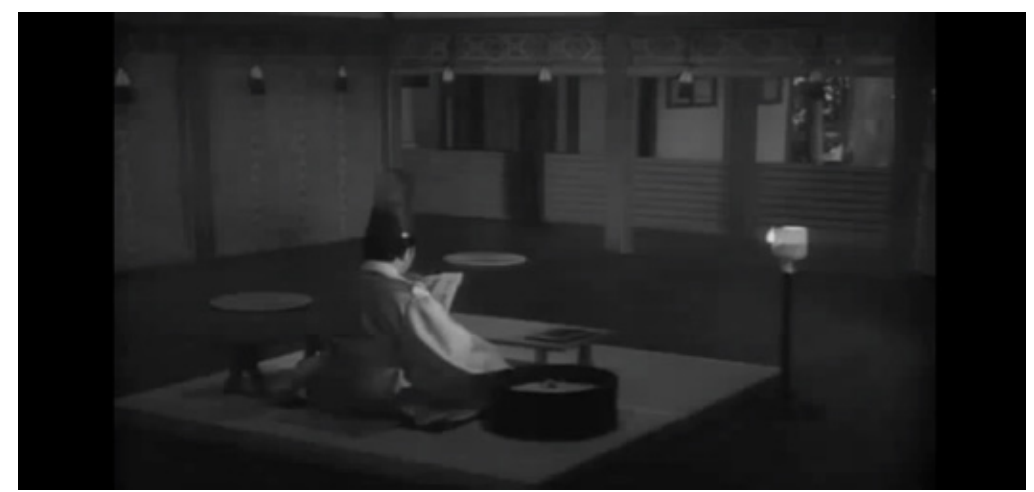

Figura 11: Zushio escreve sua carta de demissão do cargo de governador Fonte: Sanshô daŷu (O intendente Sansho, 1954). 


\section{Numa tentativa de quase desfecho, seria possível ler esse filme como um estudo de caligrafia?}

Na novela de Ogai Mori a palavra escrita também é usada, mas apenas em dois momentos. O primeiro episódio ocorre bem no início da narrativa, quando uma transeunte, a quem Tamaki-san pergunta onde poderá encontrar pouso, informa que ela deverá ler em um letreiro as ordens do governador, que interditam os moradores locais de hospedarem estrangeiros. O segundo se dá no final da novela, quando o ancião que acolhe Zushio, depois de reconhecer sua nobre linhagem, recebe notícias sobre a morte do pai do rapaz por meio de uma carta. Mas, como visto, no filme a palavra escrita é usada de maneira genial, não apenas para mostrar o poder da legislação, mas também como surpreendente recurso cênico. Basta lembrar que a materialidade da palavra escrita tem papel central nessa parte final do filme.

Em texto de 1929, “O princípio cinematográfico e o ideograma”, Serguei Eisenstein faz uma importante associação entre a maneira como se processa a criação dos ideogramas - que se dá pela combinação de dois ou mais elementos suscetíveis de serem pintados, de forma a representar algo que não pode ser graficamente retratado - com a montagem cinematográfica: "Sim, é exatamente isto que fazemos no cinema, combinando tomadas que pintam, de significado singelo e conteúdo neutro - para formar contextos e séries intelectuais. Isto constitui um recurso e um método inevitáveis em toda exposição cinematográfica" (EISENSTEIN, 1994, p. 151).

Nesse mesmo texto, o cineasta russo alega que o cinema japonês não tem a menor consciência da montagem e faz uma espécie de alerta aos cineastas nipônicos: "Compreender e aplicar suas peculiaridades culturais ao cinema: eis a tarefa do Japão! Companheiros do Japão, irão vocês realmente deixar essa tarefa para nós?” (EISENSTEIN, 1994, p. 159).

Alguns anos depois dessa declaração do mestre russo, Kenji Mizoguchi não só mostrou que os cineastas japoneses poderiam, sim, ser exímios mestres da montagem, como, de acordo com o crítico de cinema Tadao Sato, filmava e montava seus filmes como se estivesse intimamente associado à caligrafia japonesa

um acto vital, como a respiração - a energia é a quantidade de tinta que há no pincel, depois começa-se lentamente a expirar, e na página em branco o mundo começa a nascer. E quando acabar a tinta no pincel tem que se começar tudo de novo. É uma coisa gestual, uma coisa de corpo. Na caligrafia tradicional, a escrita e a pintura são a mesma coisa. (apud ROCHA, 2000, p. 57) 
Jacques Rancière retoma as ideias de Eisentein para acentuar que em essência o cinema reverberava em todas as artes nipônicas inspiradas no princípio ideogramático, como os haikais e o kabuki na pintura.

O princípio da arte cinematográfica é, efectivamente, o da língua ideogramática. Mas essa própria língua é dupla. O ideograma é um significado engendrado de duas imagens. Tal como as imagens combinadas da água e dos olhos compõem o significado do choro, o choque entre dois planos ou dois elementos visuais de um plano compõe, contra o valor mimético dos elementos representados, um significado - o elemento de um discurso onde a ideia ganha directamente imagem, de acordo com o princípio da dialética dos contrários. A arte 'ideogramática' do kabuki é a arte da montagem e da contradição. [...] E a montagem por sua vez, herda o poder dessa língua. (RANCIÈRE, 2014, p. 44)

Ernest Fenollosa, que estudou durante anos não apenas a poesia chinesa, mas também a maneira como ela estava em profunda relação com a construção ideográfica, bem nos explica que, diferente das línguas fonéticas, em que a relação entre o signo e o significado é arbitrária, os ideogramas funcionam de outra forma. $\mathrm{Na}$ escrita composta por ideogramas, os signos usados evocam uma imagem-ideia tão perfeitamente associada ao vivido e ao concreto que a palavra parece estar viva. Ora, se a poesia oriental tem a inigualável vantagem de propiciar a vivacidade da pintura e a mobilidade dos sons, ou, como bem sintetiza Fenollosa, "gran número de esos radicales ideográficos llevan en sí mismos una idea verbal de acción [...] y el ojo ve nombre y verbo como una sola cosa, cosas en movimiento" (FENOLLOSA, 2001, p. 35), o que dizer de um filme como O intendente Sansho?

Como vimos, nessa película a palavra percorre um caminho cíclico: é ditada pelo governador, toma forma de ideograma pelas mãos do escriba, é passada de mão em mão quando pintada na tabuleta e depois ganha novamente a forma de palavra falada, pois é pela boca do governador que os escravizados são libertos. Então, não apenas os seres humanos ganham liberdade, mas também a própria palavra, que ecoa da boca de Zushio até os ouvintes, deixou de ser ideograma e voltou à forma oral.

Diferente não é o que acontece com os nomes dos protagonistas, que de gritos se fizeram canção, transportados pela voz da jovem que canta na sala de tear. Essa canção é usada como sonorização de outras cenas para, finalmente, ser murmurada pela mãe no desfecho do filme. Assim, tanto a palavra escrita como a palavra cantada caminham pela tela. O mesmo ocorre com a estatueta da deusa: dada pelo pai ao filho, passa para as mãos de Anju quando o irmão a deita fora, repousa 
sobre o corpo da moribunda Najimi-san, de onde é retirada por Zushio, vai parar nas mãos dos guardas, que a entregam ao primeiro-ministro para ser devolvida ao jovem, e é tateada pela mãe na cena de reconhecimento ao final do filme.

Essa circularidade é encontrada também na trajetória de Zushio, que ocupa o lugar que fora do pai como governador e, como fizera o progenitor, abre mão desse poder para ser misericordioso com os outros.

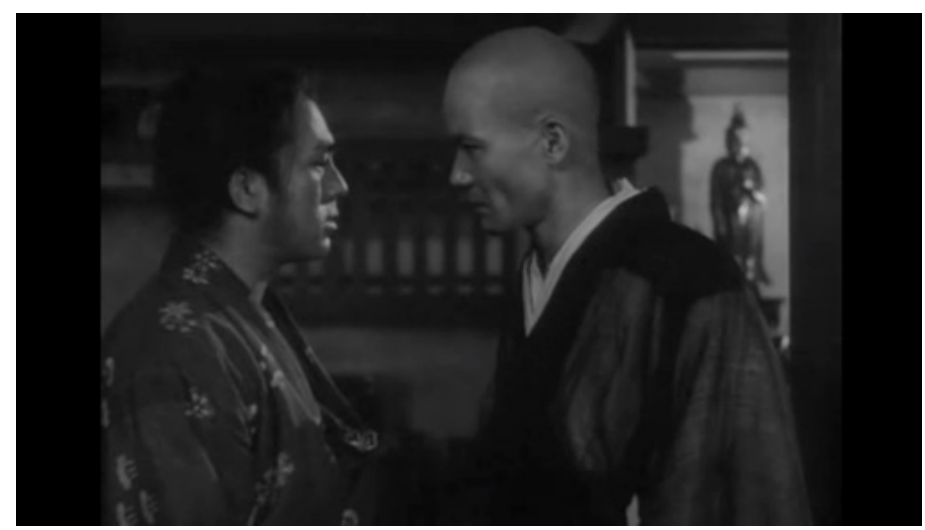

Figura 12: Nesta cena, em que o monge Taro conversa com Zushio no templo, pode-se ver uma estátua de Kannan ao fundo. Marca do preciosismo de Mizoguchi em cada detalhe Fonte: Sanshô daŷu (O intendente Sansho, 1954).

Atrevo-me a ir mais além. Talvez não tenha sido por acaso o foco nas mãos do escriba que registra as palavras do imperador: o movimento tão perceptível, mesmo para quem não sabe absolutamente nada de japonês, a mostrar que a escrita é feita da direita para a esquerda é como também se movimenta a câmera com frequência em O intendente Sansho. Sobretudo nos momentos de maior tensão, como na sequência em que Anju reconhece as palavras da mãe em uma canção e nas cenas que narram a morte da jovem, a câmera faz o mesmo caminho que o pincel.

Aliás, é o que ocorre também no final do filme. Depois da cena comovente de reconhecimento, em que a panorâmica horizontal está focada nas personagens a chorar abraçadas, há um amplíssimo movimento da câmera que "caminha" da direita para a esquerda e nos mostra o homem que está a secar algas - último ideograma pintado pelo magistral caligrafista-cineasta Mizoguchi sobre a tela.

\section{Referências}

CHKLOVSKI, V. “A construção da novela e do romance”. In: TODOROV, T. (Org.). Teoria da literatura II. Lisboa: Edições 70, 1989. p. 41-68. 
COSTA, J. B. da. "Mizoguchi: a quinta essência". In: CINEMATECA PORTUGUESA. Ciclo Kenji Mizoguchi. Lisboa: Museu do Cinema, 2000. p. 15-35.

EISENSTEIN, S. "O princípio cinematográfico e o ideograma”. In: CAMPOS, H. (Org.). Ideograma, lógica, poesia e linguagem. São Paulo: Edusp, 1994. p. 149- 166.

FENOLLOSA, E. El carácter de la escritura china como médio poético. Trad. Mariano Antolín Rato. 2. ed. Barcelona: Visor Libros, 2001.

MADEIRA, M. J. “Zangiku Monogatari: contos dos crisântemos tardios". In: RODRIGUES, A. (Org.). As folhas da Cinemateca: Kenji Mizoguchi. Lisboa: Cinemateca Portuguesa, 2005. p. 45-50.

MORI, O. El intendente Sansho. Trad. Elena Gallego. Zaragoza: Contraseña, 2014.

RANCIÈRE, J. A fábula cinematográfica. Trad. Luís Lima. Lisboa: Orfeu Negro, 2014.

ROCHA, P. "Paulo Rocha fala sobre Kenji Mizoguchi”. In: CINEMATECA PORTUGUESA. Ciclo Kenji Mizoguchi. Lisboa: Museu do Cinema, 2000. p. 56-70.

STAM, R. "Teoria e prática da adaptação: da fidelidade à intertextualidade". Ilha do Desterro, Florianópolis, n. 51, jul./dez. 2006. Disponível em: <https://bit.ly/2I47Nro>. Acesso em: 28 mai. 2018.

YODA, Y. Souvenirs de Kenji Mizoguchi. Paris: Cahiers du cinéma, 1997.

\section{Referências audiovisuais}

SANSHÔ dayû (O intendente Sansho). Kenji Mizoguchi, Japão, 1954.

submetido em: 10 jan. 2018 | aprovado em: 10 maio 2018 